\title{
Inibição e inativação in vitro de diferentes métodos de extração de Ocimum gratissimum L. ("alfavacão", "alfavaca”, "alfavaca-cravo") - Labiatae(Lamiaceae), frente a bactérias de interesse em alimentos
}

PASSOS, M.G.; CARVALHO, H.; WIEST, J.M.

Programa de Pós-Graduação em Ciência e Tecnologia de Alimentos, Instituto de Ciências e Tecnologia de Alimentos, Universidade Federal do Rio Grande do Sul, Brasil. * Correspondência: J.M.Wiest-ICTA/UFRGS, Campus do Vale, Avenida Bento Gonçalves, 9500, Caixa Postal 15090, CEP 91505-970, Porto Alegre - RS/Brasil. E-mail: jmwiest@ufrgs.br

\begin{abstract}
RESUMO: Através de testes de diluição em sistema de tubos múltiplos determinou-se a intensidade de atividade de inibição bacteriana (IINIB/bacteriostasia) e a intensidade de atividade de inativação bacteriana (IINAB/bactericidia) de soluções conservantes contendo extratos etanólicas (alcoolatura/planta in natura, hidroalcoolatura/planta seca) e hídricas (decoctos /planta in natura ou seca) de Ocimum gratissimum L. ("alfavacão", "alfavaca", "alfavaca-cravo") - Labiatae (Lamiaceae), sobre inóculos padronizados de Salmonella enteritidis (ATCC 11076), Escherichia coli (ATCC 11229) e Staphylococcus aureus (ATCC 25923). Todas as diferentes formas de extração apresentaram capacidade de inibição e/ou inativação seletivas sobre os inóculos bacterianos, tendo o extrato alccólico apresentado a atividade antibacteriana mais intensa (inibição/inativação) frente aos três agentes. Abactéria mais sensível à atividade antibacteriana em todas as soluções conservantes foi Salmonella enteritidis. Staphylococcus aureus apresentou a menor sensibilidade às formas de decocção, enquanto Escherichia coli apresentou a menor sensibilidade frente ao extrato hidroalcoólico.
\end{abstract}

Palavras-chave: Ocimum gratissimum, atividade antibacteriana, inibição bacteriana, inativação bacteriana, extratos vegetais

\begin{abstract}
In vitro inhibition and inactivation of different extraction methods in Ocimum gratissimum L. ("alfavacão", "alfavaca", "alfavaca-cravo") - Labiatae (Lamiaceae) against foodborne bacteria of interest. Dilution tests in multiple tube system were used to evaluate the intensity of bacterial inhibition activity (IINIB/bacteriostasis) and bacterial inactivation activity (IINAB/ bactericide) of conserver solutions containing ethanolic (alcoholature/in natura plant, hidroalcoholature/dry plant) and aqueous (decoctions/in natura or dry plant) extracts of Ocimum gratissimumL. ("alfavacão", "alfavaca”, "alfavaca-cravo") - Labiatae - (Lamiaceae) on standardized inocula of Salmonella enteritidis (ATCC 11076), Escherichia coli(ATCC 11229) and Staphylococcus aureus (ATCC 25923). All the different extraction methods presented selective inhibition and/or inactivation on the bacterial inocula. The alcoholic extract had the highest antibacterial activity (inhibition/inactivation) against the three agents. Salmonella enteritidis was the most sensitive to the antibacterial activity in all conserver solutions. Staphylococcus aureus showed the lowest sensitivity to decoctions, whereas Escherichia coli was the least sensitive to the hydroalcoholic extraction.
\end{abstract}

Key words: Ocimum gratissimum, antibacterial activity, bacterial inhibition, bacterial inactivation, plant extracts

\section{NTRODUÇ̃̃O}

Os recursos naturais renováveis representados pelas plantas medicinais, condimentares e aromáticas, participam do cotidiano das ações de saúde e de alimentação, através de seus inúmeros princípios ativos e biocomplexos extraídos de diferentes modos e processos incluindo os decoctos, os infusos, os

Recebido para publicação em 21/01/2008

Aceito para publicação em 19/05/2008

Rev. Bras. PI. Med., Botucatu, v.11, n.1, p.71-78, 2009. 
macerados, as tinturas, as alcoolaturas, envolvendo diferentes solventes, permitindo o estudo dos extratos na condição de droga crua ou purificada, partindo-se de plantas in natura ou verdes ou plantas desidratadas, entre outros processos (Sullivan, 1997).

O gênero Ocimum pertence à família Labiatae (Lamiaceae), abrangendo trinta espécies que são encontradas em regiões tropicais e subtropicais. Ocimum gratissimumL. é uma planta que possui aroma forte e agradável, popularmente chamado de "alfavacão", "alfavaca" ou "alfavacacravo", com origem no oriente, subespontâneo em todo o Brasil e do qual existem diversos quimiotipos. Várias espécies de Ocimum são plantas classicamente fornecedoras de óleos essenciais, largamente utilizados como temperos de pratos especiais e como aromatizantes de licores e de perfumes finos (Lorenzi \& Matos, 2002).

Medicinalmente, Ocimum gratissimumé utilizado frente a várias doenças tais como: leishmanioses, infecções do trato respiratório superior, diarréia/antidiurese, desordem gastrointestinal, febre tifóide, dor de cabeça, doenças de pele e oftamológicas, sendo muito comum na medicina caseira o uso de seu chá como carminativo, sudorífico e diurético. A planta apresenta inúmeros compostos, sendo o eugenol o composto majoritário (Ueda-Nakamura et al., 2006; Sartoratto et al., 2004; Lorenzi \& Matos, 2002; llori et al., 1996).

A utilização de óleos essênciais de plantas como redutor de microrganismos patogênicos para a conservação de alimentos vem crescendo devido ao interesse em substituir compostos químicos sintéticos por substâncias naturais. Estes compostos podemser responsáveis por atributos carcinogênicos, teratogênicos e também apresentar toxicidade residual (Moreira et al., 2005). Outro fator relevante para a busca por conservantes naturais é que muitos microrganismos patogênicos adquirem resistência aos antibióticos, havendo a necessidade de serem substituídos por produtos de origem natural (Sartoratto et al., 2004). Estudos vêm sendo realizados para avaliar a atividade antimicrobiana e antifúngica de plantas medicinais (Chah et al., 2006; Faria et al., 2006). Ocimum gratissimum, por sua vez, apresenta esta propriedade conservante devido às substâncias encontradas emseu óleo essencial tais como: cimen8-ol, eugenol e trans-cariofileno, entre outras (Sartoratto et al., 2004; Nguefack, 2004; Nakamura et al., 1999; Ilori et al., 1996). Orafidiya et al., (2002) descrevematividade antibacteriana em formulações comóleo essencial de Ocimum gratissimum utilizadas como antissépticas no tratamento de feridas ou lesões com solução de continuidade. Oussou et al., (2004) testaram óleo essencial do gênero Ocimum, entre estes $O$. gratissimum, frentea 14 bactérias diferentes originárias da Costa do Marfim demostrando atividade bacteriostática e bactericida relevantes nesta planta.

Eugenol é o composto químico em maior percentual no óleo essencial da planta Ocimum gratissimum, podendo este valor variar emfunção da técnica de extração e do acesso. Este composto apresenta uma série de atributos farmacológicos tais como: agente aromático para alimentos, anticonvulsivo, anestésico, analgésico dentário, antibactericida e fungicida (Ueda-Nakamura, 2006; Sartoratto et al., 2004; Lorenzi \& Matos; 2002).

Este trabalho tem como objetivo determinar in vitro a atividade antibacteriana de extratos etanólicos (alcoolatura/planta verde e hidroalcoolatura /planta seca, com evaporação do etanol em sistema rota-vapor com reconstituição hídrica posterior sob condições de assepsia) e extratos hídricos (decoctos de planta verde e seca, idem quanto à reconstituição) de um acesso de Ocimum gratissimum, constituído de um "pool" de exemplares subespontâneos, originários do Município de Eldorado do SulRS, frente a agentes bacterianos padrões internacionais de interesse em alimentos, respectivamente Staphylococcus aureus (ATCC 25923), Escherichia coli (ATCC 11229) e Salmonella enteritidis (ATCC 11076), atividade esta expressa como IINIB (Intensidade de Inativação Bacteriana/bacteriostasia) e como IINAB (intensidade de Inativação Bacteriana/ bactericidia), relacionando-a, outrossim, como tempo de confrontação bactérias versus diferentes extratos. Em síntese, manipulam-se as variáveis: bactérias, os diferentes tipos de extração, os tempos de confrontação e a presença ou ausência de desinibidores bacterianos, permanecendo constante em $50 \%$ a concentração final de uso dos diferentes extratos nas denominadas soluções conservantes.

\section{MATERIALE MÉTODO}

A planta Ocimum gratissimum foi colhida em propriedade agroecológica familiar em Parque Eldorado, Município de Eldorado do Sul, região metropolitana de Porto Alegre, RS/Brasil, Depressão Central (coordenadas de 300 $05^{\prime} \mathrm{S}$ e 5140' W), constituindo um "pool" de partes vegetativas e reprodutivas de exemplares subespontâneos, ruderais. Segundo a escala ACFOR de Kent \& Coker (1992), nesta propriedade Ocimum gratissimumse classificou na categoria de "freqüente". Aplicando a escala de sociabilidade de Braun-Blanquet (1979) a planta se apresentava em pequenos grumos ou tufos de indivíduos não cultivados.

O material foi herborizado segundo Ming (1996) e catalogado pela bióloga Silvia Marodin (CRBio/RS n.17268), sendo a duplicata botânica 
incorporada ao Herbário do Departamento de Botânica, do Instituto de Biociências, da Universidade Federal do Rio Grande do Sul, recebendo número de registro 150160 .

Talos, folhas e flores da planta foram submetidos aos processos de extração alcoólica (alcoolatura/planta in natura), extração hidroalcóolica (hidroalcoolatura/planta seca) e decocção (planta seca e in natura) para obtenção das soluções conservantes ou antibacterianas, segundo Farmacopéia (1959). As amostras vegetais recém colhidas foram trituradas grosseiramente e colocadas em álcool etílico, de cereais (Farmaquímica, Porto Alegre/RS/BR) a $96^{\circ} \mathrm{GL}$, na proporção de $400 \mathrm{~g}$ de planta para 1000 $\mathrm{mL}$ de álcool, na extração alcoólica. O extrato hidroalcoólico foi elaborado a partir de planta seca, colocado em álcool etílico, de cereais, a $70^{\circ} \mathrm{GL}$, na proporção de $100 \mathrm{~g}$ de planta para $1000 \mathrm{~mL}$ de álcool. Após um período de quinze dias, ambos os extratos foram submetidos à destilação fracionada sob pressão reduzida em sistema rota vapor, desprezando-se a porção alcoólica e reidratandose o extrato resultante com água destilada estéril, reconstituindo-se as concentrações iniciais da planta.

O decocto de planta seca foi preparado a partir da planta desidratada na proporção de $100 \mathrm{~g}$ de planta para $1000 \mathrm{~mL}$ de água destilada estéril, mantido sob fervura durante 20 minutos em aquecedor com refluxo repondo-se o volume inicial. Já o decocto de planta in natura foi realizado no momento da chegada da planta ao Laboratório de Higiene, Instituto de Ciência e Tecnologia de Alimentos (ICTA) da Universidade Federal do Rio Grande do Sul, sendo realizado na proporção de $400 \mathrm{~g}$ da planta para $1000 \mathrm{~mL}$ de água destilada estéril. Para viabilizar a extração hidroalcoólica e o decocto de planta seca, parte da planta foi pesada e colocada em estufa com circulação de ar forçada e temperatura constante de $40^{\circ} \mathrm{C}$, procedendo-se varias pesagens até a estabilização de seu peso. Para o controle permanente da assepsia destes procedimentos de extração e reconstituição, determinou-se a esterilidade de todos as soluções conservantes ou antibacterianas, retirando-se alíquota de $5 \mathrm{~mL}$, semeada em tubos de Caldo BHI (Brain Hearth Infusion, ACUMEDIA, USA), incubados aeróbiamente à $37^{\circ} \mathrm{C}$ por até 48 horas, confirmando-se por plaqueamento em Agar Nutriente (Nutrient Agar, ACUMEDIA, USA).

Foram utilizadas amostras de inóculos padrões American Culture Colletion (ATCC), para a avaliação da atividade antibacteriana (IINIB/ bacteriostasia e IINAB/bactericidia) dos diferentes extratos de plantas tendo sido estas: Staphylococcus aureus (ATCC 25923), Escherichia coli (ATCC 11229) e Salmonella Enteritidis (ATCC 11076), provenientes da coleção-bacterioteca do Laboratório de Higiene de Alimentos do ICTA/ UFRGS. Os inóculos foram reativados em meio de cultura $\mathrm{BHI}$ à $37^{\circ} \mathrm{C}$ por um período de 18 a 24 horas de incubação aeróbia, com o objetivo de atingir uma concentração $\geq 1,0 \times 10^{8}$ UFC $\mathrm{mL}^{-1}$ para confrontação com os diferentes extratos de O. gratissimum, através de diluições seriais logarítmicas (Avancini, 2002). A avaliação da concentração inicial foi realizada através da técnica da microgota segundo Romeiro (2007) e a contagem de microrganismos viáveis foi concretizada em placas de Petri contendo meio de cultura PCA (Plate Count Agar, HIMEDIA, Índia).

As diluições seriadas foram realizadas a partir do inóculo inicial, transferindo-se $1 \mathrm{~mL}$ deste para tubos de ensaio contendo $9 \mathrm{~mL}$ de água peptonada 0,1\% (BIOBRÁS, Montes Claros, Minas Gerais, Brasil) para obter a diluição $10^{-1}$, e assim sucessivamente até a diluição $10^{-12}$. De cada diluição foram transferidas três gotas para placas de Petri utilizando micropipetas de $15 \mu \mathrm{L}$ e a leitura realizada em 24 horas de incubação aeróbia à $37^{\circ} \mathrm{C}$. O valor final considerado constituiu-se da média das contagens das gotas triplicadas, avaliadas biometricamente segundo Cavalli-Sforza (1974).

Para a determinação da atividade antibacteriana dos extratos de Ocimum gratissimum, lida como intensidade de atividade de inibição bacteriana/bacteriostasia (IINIB) e intensidade de atividade de inativação bacteriana/ bactericidia (IINAB), utilizou-se o teste de diluição segundo Deutsche Veterinärmedizinische Gesellschaft/Sociedade Alemã de Medicina Veterinária (DVG, 1981), com base na técnica do sistema de tubos múltiplos, modificada por Avancini (2002), confrontando-se os quatro diferentes extratos com 12 diluições seriais logarítmicas $\left(10^{-1} \mathrm{a}\right.$ $10^{-12}$ UFC mL-1) dos diferentes inóculos bacterianos.

Entende-se por IINIB/bacteriostasia, o resultado do confronto da bactéria com a solução antibacteriana em meio específico, e por IINAB/ bactericidia, o mesmo resultado, porém sob a influência dos desinibidores bacterianos acrescidos ao BHI (DVG, 1981; Andrade \& Macedo, 1996; Reybrouck,1979, 1998). Estes valores são, segundo Avancini (2002), representações da atividade biológica inibitória/bacteriostasia ou inativadora/bactericidia de diferentes soluções antibacterianas sobre os microrganismos.

Os resultados de intensidade de atividade de inibição bacteriana/bacteriostasia (IINIB) e intensidade de atividade de inativação bacteriana/ bactericidia (IINAB) foram representados por variáveis ordinais arbitrárias, que assumiram valores de 12 a 
0 , sendo que o valor de 12 (doze) representa atividade máxima e 0 (zero) a não-atividade, como demonstra a Tabela 1 a seguir.

Os resultados da avaliação da atividade antibacteriana (IINIB e IINAB) das diferentes soluções conservantes extraídas de Ocimum gratissimum foram tratados através do programa de análises estatísticas Sisvar 5.0 (2007). Os resultados foram avaliados através da Análise de Variância (Anova) e teste de Tukey.

TABELA 1. Representação dos valores ordinais arbitrários de intensidade de atividade atribuídos às variáveis Intensidade da Atividade de Inibição Bacteriana/bacteriostasia (IINIB) e Intensidade de Atividade de Inativação Bacteriana/bactericidia (IINAB) e suas correspondentes diluições e doses infectantes dos inóculos.

\begin{tabular}{|c|c|c|c|c|c|c|c|c|c|c|c|c|c|}
\hline 12 & 11 & 10 & 9 & 8 & 7 & 6 & 5 & 4 & 3 & 2 & 1 & 0 & $\begin{array}{l}\text { Variáveis } \\
\text { ordinárias de } \\
\text { intensidade de } \\
\text { atividade }\end{array}$ \\
\hline $10^{-1}$ & $10^{-2}$ & $10^{-3}$ & $10^{-4}$ & $10^{-5}$ & $10^{-6}$ & $10^{-7}$ & $10^{-8}$ & $10^{-9}$ & $10^{-10}$ & $10^{-11}$ & $10^{-12}$ & n.a & $\begin{array}{l}\text { UFC/mL - } \\
\text { diluições de } \\
\text { inoculo inibidas } \\
\text { ou inativadas }\end{array}$ \\
\hline $10^{7}$ & $10^{6}$ & $10^{5}$ & $10^{4}$ & $10^{3}$ & $10^{2}$ & $10^{\prime}$ & 1 & $10^{-1}$ & $10^{-2}$ & $10^{-3}$ & $10^{-4}$ & n.a & $\begin{array}{l}\text { UFC/mL - doses } \\
\text { infectantes } \\
\text { inibidas ou } \\
\text { inativadas }\end{array}$ \\
\hline
\end{tabular}

n.a: ausênsia de atividade antibacteriana; UFC. $\mathrm{mL}^{-1}$ : unidades formadoras de colônias por $\mathrm{mL}$.

\section{RESULTADO E DISCUSSÃO}

Os resultados da atividade antibacteriana das quatro formas de extração de Ocimum gratissimum à $50 \%$, independentes dos fatores tempo de confrontação, espécies bacteriana e presença ou ausência de desinibidores bacterianos, encontramse na Tabela 2.

Quando avaliada a sensibilidade das três espécies bacterianas frente a soluções conservantes de Ocimum gratissimum, independentemente das demais variáveis manipuladas, houve diferença significativa entre as bactérias, como mostra a Tabela 3. A bactéria que apresentou maior sensibilidade à atividade antibacteriana foi Salmonella enteritidis, superior às demais, seguida de Escherichia coli e Staphylococcus aureus.

Quando avaliados os dois tratamentos com desinibidores/bactericidia (IINAB) e sem desinibidores/ bacteriostasia (IINIB), independentemente das demais variáveis manipuladas, observou-se diferenças significativas como mostra a Tabela 4. O tratamento IINIB (bacteriostasia/inibição pela ausência de desinibidores) apresenta resultado superior ao de IINAB (bactericidia/inativação pela presença de desinibidores), ou seja, a ação bacteriostática das soluções conservantes de Ocimum gratissimum é

TABELA 2. Intensidade da Atividade de Inibição Bacteriana /bacteriostasia (IINIB) e Intensidade da Atividade Inativação Bacteriana/bactericidia (IINAB) de diferentes extratos à 50\% de Ocimum gratissimum - Labiatae (Lamiaceae) - segundo diferentes tempos de exposição e a presença ou ausência de desinibidores bacterianos, observados em triplicata.

\begin{tabular}{|c|c|c|c|c|c|c|c|c|c|c|c|c|c|c|c|c|c|c|c|}
\hline \multirow{2}{*}{$\begin{array}{l}\text { Tipo de } \\
\text { Extrato }\end{array}$} & \multicolumn{7}{|c|}{$\begin{array}{c}\text { Staphylococcus } \\
\text { aureus }\end{array}$} & \multicolumn{6}{|c|}{ Salmonella enteritidis } & \multicolumn{6}{|c|}{ Escherichia coli } \\
\hline & (h) & \multicolumn{3}{|c|}{ IINIB } & \multicolumn{3}{|c|}{ IINAB } & \multicolumn{3}{|c|}{ IINIB } & \multicolumn{3}{|c|}{ IIN AB } & \multicolumn{3}{|c|}{ IIN IB } & \multicolumn{3}{|c|}{$\| \mathrm{N} A \mathrm{~B}$} \\
\hline \multirow{3}{*}{ Alcœolatura } & 24 & 3 & 3 & 3 & 2 & 2 & 2 & 11 & 11 & 11 & 8 & 8 & 8 & 11 & 11 & 11 & 4 & 4 & 4 \\
\hline & $\mathbf{A B}$ & 3 & 3 & 3 & 2 & 2 & 2 & 12 & 12 & 12 & 8 & 8 & $\mathrm{~s}$ & 12 & 12 & 12 & 2 & 2 & 2 \\
\hline & 72 & 2 & 2 & 2 & 2 & 2 & 2 & 12 & 12 & 12 & 8 & 8 & 8 & 12 & 12 & 12 & 2 & 2 & 2 \\
\hline \multirow[t]{4}{*}{ Hidroakocl atura } & $4 \mathrm{~B}$ & 2 & 2 & 2 & 0 & 0 & 0 & 8 & 8 & 8 & 0 & 0 & 0 & 2 & 2 & 2 & 0 & 0 & 0 \\
\hline & 72 & 2 & 2 & 2 & 0 & 0 & 0 & 8 & 8 & 8 & 0 & 0 & 0 & 2 & 2 & 2 & 0 & 0 & 0 \\
\hline & 144 & 3 & 3 & 3 & 0 & 0 & 0 & 7 & 7 & 7 & 0 & 0 & 0 & 0 & 0 & 0 & 0 & 0 & 0 \\
\hline & 24 & 0 & 0 & 0 & 0 & 0 & 0 & 4 & 4 & 4 & 1 & 1 & 1 & 3 & 3 & 3 & 1 & 1 & 7 \\
\hline \multirow[t]{2}{*}{ Decocto Verde } & 48 & 0 & 0 & 0 & 0 & 0 & 0 & 4 & 4 & 4 & 1 & 1 & 1 & 0 & 0 & 0 & 1 & 1 & 1 \\
\hline & 72 & 0 & 0 & 0 & 0 & 0 & 0 & 3 & 3 & 3 & 0 & 0 & 0 & 0 & 0 & 0 & 1 & 1 & 1 \\
\hline
\end{tabular}

Rev. Bras. PI. Med., Botucatu, v.11, n.1, p.71-78, 2009. 
TABELA 3. Avaliação da sensibilidade de três espécies bacterianas de interesse em alimentos frente à soluções conservantes de Ocimum gratissimum, independente dos fatores tipo de extração, tempo de confrontação, presença ou ausência de desinibidores bacterianos.

\begin{tabular}{lc}
\hline Espécies bacterianas & Número Arbitrário \\
Staphylococcus aure us (ATCC 25923) & $0,91^{\mathrm{a}^{+}}$ \\
Escherichia coli (ATCC 11229) & $2.34^{\mathrm{b}}$ \\
Salmonella enteritidis (ATCC 11076) & $4,50^{\mathrm{C}}$ \\
\hline
\end{tabular}

Letras minúsculas diferentes sobrescritas ( $\underline{a}$ ) na mesma coluna indicam diferenças significativas entre as espécies bacterianas para a análise de variância (Anova) e teste de Tukey $(p<0,05)$.

TABELA 4. Avaliação da presença ou da ausência de desinibidores bacterianos na atividade antibacteriana de soluções conservantes de Ocimum gratissimum, independente dos fatores tempo de confrontação, tipo de extração e espécie bacteriana.

\begin{tabular}{lc}
\hline Tratamen tos com presença ou ausência de desinibidores & Número Arbitrário \\
IINAB / bacte ricidia (presença dos desinibidores bacterianos) & $1,31^{0}$ \\
IINIB / bacteriostasia (ausência de desinibidores bacterianos) & $3,85^{\mathrm{b}}$ \\
\hline
\end{tabular}

Letras minúsculas diferentes sobrescritas ( $\stackrel{a}{\text { ) }}$ na mesma coluna indicam diferenças significativas entre as espécies bacterianas para a análise de variância (Anova) e teste de Tukey $(p<0,05)$.

superior a ação bactericida. Souza (2005), Girolometto (2005) e Carvalho et al. (2005) testando outras plantas e aplicando a mesma metodologia também obtiveram resultados superiores para IINIB em relação ao IINAB.

A Tabela 5 avalia a atividade antibacteriana dos extratos de Ocimum gratissimum obtidos a partir de diferentes tipos de extração sobre as principais bactérias causadoras de toxinfecções alimentares. Dentre estas Staphylococcus aureus apresentou diferença significativa em todos os tipos de extração. Sendo o extrato alcoólico aquele que apresenta maior ação sobre Staphylococcus aureus, seguido da forma hidroalcoólica e da decocção de planta seca, sendo que a atividade antiestafilocócica do extrato obtido através da decocção de planta in natura foi nula. A atividade antibacteriana de $O$. gratissimum sobre Salmonella enteritidis apresenta diferença significativa entre todos os tipos de extração, sendo que a atividade mais intensa foi observada no extrato alcoólico. Já as atividades dos extratos obtidos por hidroalcoolatura e decocção de planta seca sobre Escherichia coli não apresentam diferença significativa. Observa-se, novamente, maior ação antiescherichia no extrato obtido por alcoolatura.

Quando avaliadas os quatro métodos de extração (Tabela 5), independentemente das demais variáveis manipuladas, estas diferiram significativamente entre si. A extração alcoólica apresenta valor superior aos demais tipos de extração, seguido pela hidroalcoolatura, pelo decocto de planta seca e pelo decocto de planta in natura. Souza (2005) e Girolometto (2005), embora testando outras plantas, com a mesma metodologia, também obtiveram resultados superiores para a forma de extração alcoólica e inferiores para os decoctos. Uma hipótese

TABELA 5. Avaliação da relação entre as espécies bacterianas de interesse em alimentos e os diferentes tipos de extração de Ocimum gratissimum, independente dos fatores tempo de confrontação, presença ou ausência de desinibidores bacterianos.

\begin{tabular}{lccc}
\hline Tipos de Extraçäo & Staphylococcus aureus & Salmonella Enteritidis & Escherichia coli \\
Decocto com planta verde & $0,00^{\mathrm{aA}}$ & $2,00^{\mathrm{aB}}$ & $0,75^{\mathrm{aC}}$ \\
Decocto com planta seca & $0,38^{\mathrm{bA}}$ & $2,50^{\mathrm{bB}}$ & $0,63^{\mathrm{abB}}$ \\
Hidroalcoolatura (planta seca) & $1,13^{\mathrm{cA}}$ & $3,63^{\mathrm{cB}}$ & $0,88^{\mathrm{bC}}$ \\
Alcoolatura (planta verde) & $2,13^{\mathrm{dA}}$ & $9,88^{\mathrm{dB}}$ & $7,13^{\mathrm{cC}}$ \\
\hline
\end{tabular}

Letras minúsculas diferentes sobrescritas ( ${ }^{a}$ ) na mesma coluna indicam diferenças significativas entre os tipos de extração e letras maiúsculas diferentes sobrescritas ( $\mathrm{A}$ ) na mesma linha indicam diferenças significativas entre as espécies bacterianas para a análise de variância (Anova) e teste de Tukey $(p<0,05)$. 
para estas diferenças pode estar relacionada à perda de componentes como óleos essenciais, mais especificamente o eugenol, cimen-8-ol e transcariofileno, nas extrações por decocção, quando se utilizam temperaturas mais elevadas (ebulição), em comparação coma hidroalcoolatura e alcoolatura.

Quando avaliada a ação antibacteriana individualmente, relacionada a cada método de extração, sobre as três diferentes bactérias, houve diferença significativa em todos os tipos de extração. Salmonella enteritidisapresenta a maior sensibilidade antibacteriana em relação a todos os tipos de extração. Staphylococcus aureus apresenta a menor sensibilidade à extração alcoólica, à decocção da planta verde e da planta seca. Já na forma de extração hidroalcoólica, a menor sensibilidade antibacteriana é demonstrada por Escherichia coli.

Em números absolutos, os três maiores valores de sensibilidade antibacteriana são encontrados, em ordem decrescente, nas formas de extração alcoólica atuando sobre a Salmonella enteritidis e Escherichia coli, bem como na forma de extração hidroalcoólica atuando sobre a Salmonella enteritidis, embora menor.

ATabela 6 avalia a presença ou ausência de desinibidores atuando sobre as diferentes bactérias. Os resultados apresentam uma maior atividade bactericida (IINAB, com desinibidor) frente a Salmonella enteritidis, seguida da Escherichia colie Staphylococcus aureus, sendo que todos os valores são diferentes significativamente entre si. Já a maior atividade bacteriostática (IINIB, sem desinibidor) é observada frente a Salmonella enteritidis, seguida de Escherichia colie Staphylococcus aureus, sendo que todos os valores são diferentes significativamente entre si. Nos resultados obtidos destaca-se, novamente, como na Tabela 4, que a ação bacteriostática foi maior que a bactericida (IINIB>IINAB).

Outros autores descrevem atividade bactericida usando a planta Ocimumgratissimum sobre as mesmas três bactérias, porém comoutras técnicas de avaliação de sensibilidade antimicrobiana. Sartorrato et al. (2004) e Nguefack et al. (2004) observaramatividade bactericida frente Staphylococcus aureus. Por sua vez, Nakamura et al. (1999) também descreveramatividade bactericida significativa sobre

TABELA 6. Avaliação da relação entre a sensibilidade das espécies bacterianas de interesse em alimentos e as soluções conservantes de Ocimum gratissimum, na presença ou ausência de desinibidores bacterianos, independente dos fatores tempo de confrontação e tipo de extração.

\begin{tabular}{lcc}
\hline Bactérias & \multicolumn{2}{c}{ Tratamentos com presença ou ausência de desinibidores } \\
\cline { 2 - 3 } & IINAB & IINIB \\
\hline Staphylococcus aureus & $0,50^{\mathrm{aA}}$ & $1,31^{\mathrm{a}^{\mathrm{B}}}$ \\
Escherichia coli & $0,81^{\mathrm{EA}}$ & $3,88^{\mathrm{bB}}$ \\
Salmonella enterifidis & $2,63^{\mathrm{cA}}$ & $6,38^{\mathrm{CD}}$ \\
\hline
\end{tabular}

Letras minúsculas diferentes sobrescritas $\left({ }^{a}\right.$ ) na mesma coluna indicam diferenças significativas entre as espécies bacterianas e letras maiúsculas diferentes sobrescritas ( ${ }^{A}$ ) na mesma linha indicam diferenças significativas entre os tratamentos com presença e ausência de desinibidor bacteriano, para a análise de variância (Anova) e teste de Tukey $(p<0,05)$.

Staphylococcus aureus, porém menor frente a Salmonella enteritidis e Escherichia coli.

ATabela 7 avalia os tipos de tratamento com e sem desinibidor, mostrando a atuação destes (IINIB/ bacteriostasia e IINAB/bactericidia) relacionando-os às diferentes formas de extração, independentemente dos demais fatores. Os resultados mostraramque a forma de extração alcoólica produz extratos de Ocimum gratissimum com maior atividade bactericida (IINAB, com desinibidor), enquanto que o extrato obtido por hidroalcoolatura apresenta atividade nula, sendo que todos os valores são diferentes significativamente entre si. A maior atividade bacteriostática (IINIB, sem desinibidor) é observada também na forma de extração alcoólica, seguida da hidroalcoólica, da decocção de planta seca e da decocção de planta in natura, sendo que todos os valores foram diferentes significativamente entre si.
Quando avaliadas individualmente para cada tipo de extrato, as atividades bactericida (IINAB, com desinibidor) e bacteriostática (IINIB, sem desinibidor), apresentam sempre diferenças significativas.

Em síntese, todos os extratos de Ocimum gratissimum originados das diferentes tipos de extração, apresentam capacidade de inibição e/ou inativação seletivas in vitro sobre os três inóculos bacterianos de interesse em alimentos estudados, tendo a forma de extração alcoólica (etanol evaporado emsistema de rota-vapor com reconstituição hídrica sobassepsia) apresentado atividade antibacteriana mais intensa (inibição/inativação) frente aos três agentes. A bactéria mais sensível à atividade antibacteriana de todos os extratos é Salmonella Enteritidis. Staphylococcus aureus apresenta a menor sensibilidade às formas de decocção, enquanto que Escherichia coli apresenta menor sensibilidade ao 
TABELA 7. Avaliação da relação entre as diferentes formas de extração das soluções conservantes de Ocimum gratissimumna presença ou ausência de desinibidores bacterianos, independente dos fatores tempo de confrontação e espécie bacteriana de interesse em alimentos.

\begin{tabular}{l|c|c}
\hline & \multicolumn{2}{|c}{ Tratamento com presença ou ausência de desinibidores } \\
Tipos de Extraçāo & IINAB & $\| \mathrm{N} \mid \mathrm{B}$ \\
Decocto com planta verde & $0,42^{\mathrm{bA} *}$ & $1,42^{\mathrm{BD}}$ \\
Decocto com planta seca & $0,67^{\mathrm{CA}}$ & $1,67^{\mathrm{bB}}$ \\
Hidroalcoolatura (planta & $0,00^{\mathrm{AA}}$ & $3,75^{\mathrm{LB}}$ \\
seca) & $4,17^{\mathrm{dA}}$ & $8,58^{\mathrm{dB}}$ \\
Alcoolatura (planta verde) & & \\
\hline
\end{tabular}

Letras minúsculas diferentes sobrescritas ( $\stackrel{a}{ }$ ) na mesma coluna indicam diferenças significativas entre as diferentes formas de extração e letras maiúsculas diferentes sobrescritas ( $\mathrm{A}$ ) na mesma linha indicam diferenças significativas entre os tratamentos com presença e ausência de desinibidor bacteriano para a análise de variância (Anova) e teste de Tukey $(p<0,05)$.

extrato de Ocimumgratissimum obtido por extração hidroalcoólica. Os resultados in vitro sugerem a perspectiva da continuidade de estudos objetivando a aplicação de diferentes métodos de obtenção de extrato de Ocimum gratissimum, tanto para serem utilizados como solução conservante como condimentos alimentares, com perspectiva de qualidade, segurança e sensorialidade alimentar.

\section{AGRADECIMENTO} continuados. Ao CNPq, pelo apoio e financiamento

\section{REFERÊNCIA}

ANDRADE, N.J.; MACÊDO, J.A.B. Higienização na indústria de alimentos. São Paulo: Varela. 1996. 182p. AVANCINI, C.A.M. Saneamento aplicado em saúde e produção animal: etnografia, triagem da atividade antibacteriana de plantas nativas do Sul do Brasil e testes de avaliação do decocto de Hypericum caprifolioatum- Cham e Schlecht. Hypericaceae (Guttiferae) - ("escadinha"/"sinapismo") para uso como desinfetante e antisséptico. 2002. 309p. Tese (Doutorado em Ciências Veterinárias) - Curso de Pósgraduação de Ciências Veterinárias, Universidade Federal do Rio Grande do Sul, Porto Alegre.

BRAUN-BLANQUET, J. Fitossociologia: bases para el estudio de lãs comunidades vegetales. 1.ed. Madrid: Ed. M. Blume Ediciones, 1979. 820p.

$\mathrm{CHAH}, \mathrm{K} . \mathrm{F}$. et al. Antibacterial and wound healing properties of methanolic extracts of some Nigerian medicinal plants. Journal of Ethnopharmacology, v.104, p.164-7, 2006.

CAVALLI-SFORZA, L. Biometrie: Grundzüge biologischmedizinische Statistic (Biometria: fundamentos de estatística viológica-médica). Stuttgart: Gustav Fisher V. 1974. p.201-4.

CARVALHO, H.H.C.; CRUZ, F.T.; WIEST, J.M. Atividade antibacteriana em plantas com indicativo etnográfico condimentar em Porto Alegre, RS/Brasil. Revista Brasileira de Plantas Medicinais, v.7, n.3, p.25-32, 2005. DVG-Deutsche Veterinärmedizinische Gesellsschaft. Richtlinien zur Prüfung chemischer Desinfektionsmittel fur die Veterinärmedizin. (Normas para o teste de desinfetantes químicos para a medicina veterinária). In: SCHLIESSER, T.; STRAUCH, D. Desinfektion in Tierhaltung, Fleisch- und Milschwirtschaf. Stuttgart: Enke Verlag, 1981. p.47-55.

FARIA, T.J. et al. Antifungal activity of essential oil isolated from Ocimum gratissimum L. (eugenol chemotype) against phytopathogenic fungi. Brazilian Archives of Biology and Technology, v.49, n.6, p.867-71, 2006.

FARMACOPÉIA dos Estados Unidos do Brasil. 2.ed. São Paulo: Siqueira, 1959. 532p.

GIROLOMETTO, G. Avaliação daatividade antibacteriana de extratos de Ilex paraguarienses A. St. Hill. ("erva mate") frente a bactérias zoonóticas em saúde e produção Animal. 2005. 71p. Dissertação (Mestrado em Ciências Veterinárias) - Faculdade de Medicina Veterinária, Universidade Federal do Rio Grande do Sul, Porto Alegre.

ILORI, M.O. et al. Antidiarrhoeal activities of Ocimum gratissimum (Lamiaceae). Journal Of Diarrhoeal Diseases Research, v.14, p.283-5, 1996.

KENT, M.; COKER, P. Vegetation description and analysis: a practical approach. London: Blackwell, 1992. 363p.

LORENZI, H.; MATOS, F.J.A. Plantas medicinais no Brasil: nativas e exóticas. Nova Odessa: Instituto Plantarum, 2002. 544p.

MING, L.C. Coleta de plantas medicinais. In: DI STASI, L.C. Plantas medicinais arte e ciência: um guia de estudo interdisciplinar. São Paulo: Editora da UNESP, 1996. p.69-86.

MOREIRA, M.R. et al. Inhibitory parameters of essential oils to reduce a foodborne pathogen. LWT-Food Science end Technology, v.38, p.565-70, 2005.

NAKAMURA, C.V. et al. Antibacterial Activity of Ocimum gratissimum L. Essential Oil. Memórias do Instituto Oswaldo Cruz, v. 9, n.5, p.675-78, 1999.

NGUEFACK, J. etal. Evaluation of five essential oils from aromatic plants of Cameroon for controlling food spoilage and mycotoxin producing fungi. International Journal of Food Microbiology, v.94, p.329-34, 2004.

ORAFIDIYA, A.O. et al. The formulation of na effective topical antibacterial product containing Ocimum gratissimum leaf essential oil. The International Journal of Aromatherapy, v.12, n.1, p.16-21, 2002.

OUSSOU, K.R. et al. Activités antibactériennes des huiles essentielles de trois plantes aromatiques de Côted'Ivoire. Chimie, v.7, p.1081-6, 2004. 
REYBROUCK, G. Efficacy of inactivators against 14 disinfectant substances. Zentralblatt für Bakteriologie und Hygiene. Abteilung I. Originale B, v.68, p.480-92, 1979. REYBROUCK, G. The testing of disinfectants. International Biodeterioration \& Biodegration, v.41, p.269-72, 1998.

ROMEIRO, R.S. Técnica de microgota para contagem de células bacterianas viáveis em uma suspensão. Laboratório de Bacteriologia de Plantas. Disciplina FIP640. Bactérias Fitopatogênicas. Roteiro das aulas práticas. Aula 08 Unidade 09 Técnica da microgota. Disponível em <http://www.ufv.br/dfp/bac/uni9.pdf>. Acesso em: 23 mar. 2007.

SARTORATTO, A. et al. Composition and antimicrobial activity of essential oils from aromatic plants used in Brazil. Brazilian Journal of Microbiology, v.35, p.275-80, 2004.
SISVAR 5.0. Softwares Downloads. Disponívelem < http: //www.dex.ufla.br/ danielff/softwares.htm>. Acesso em: 23 set. 2007.

SOUZA, A.A. Aspectos etnobiológicose avaliação da atividade antibacteriana de Aloysia gratissima (Gill et Hook) Tronc. - Verbenaceae -("garupa", "erva santa") sobre agentes de importância em saúde e produção animal. 2005. 87p. Dissertação (Mestrado em Ciências Veterinárias) - Faculdade de Medicina Veterinária, Universidade Federal do Rio Grande do Sul, Porto Alegre. SULLIVAN, K. The complete family guide to natural home remedies. Boston: ELEMENT, 1997. 256p.

UEDA-NAKAMURA,T. et al. Antileishmanial activity of Eugenol-rich essential oil from Ocimum gratissimum. Parasitology International, v.55, p.99-105, 2006. 